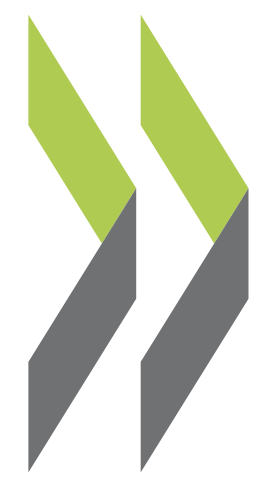

CELE Exchange, Centre for Effective Learning Environments $2010 / 12$

\title{
How Intuitive Design in Schools Can Be Achieved by Engaging with the Consumer
}

\section{Tom Doust}

https://dx.doi.org/10.1787/5km4g22g1dhl-en 


\section{How intuitive design in schools can be achieved by engaging with the consumer}

By Tom Doust, the Sorrell Foundation, United Kingdom

Over the past ten years, the Sorrell Foundation - a UK education charity - has demonstrated, through practical design projects, the advantages of involving children and young people as the main consumers of their school. The marriage of good design and consumer ownership leads to a better understanding by the user and ultimately a more profitable creation.

When Apple Inc. published its third quarter profit figures in 2010, its net profit of USD 3.25 billion ${ }^{1}$ firmly demonstrated the continuing success of its products and the use of good design to meet the needs of its consumers. At the heart of the company's success is the simplicity of using its devices, which virtually eliminates the need for an instruction manual: users find their way with ease and feel better for it.

This approach does not rely on traditional methods of market research but plays on human intuition. Devoted forums sometimes offer better support than the company's own. Success lies in using good design to bring its customer to the forefront of the product. Through its designs, consumers become better informed clients and understand the benefits that good design can have on their lives.

While schools are not products, design plays an important part in their functioning. Architectural design, spatial design, communication design and landscaping design, to name a few, are all key ingredients when refurbishing or redesigning schools. The success of their buildings and spaces is dependent on how well they relate to their users: pupils and teachers. Good education isn't exclusively linked to good design; leadership and teaching are fundamental to the school ethos, however the school environment has the power to have a significant impact on the way in which pupils connect with their education.

Over the past ten years, the UK education charity the Sorrell Foundation has demonstrated, through practical design projects, the advantages of involving children and young people as the main consumers of the school. But like Apple, it has asked consumers to be clients in the design process, leaving the actual design to the professionals but challenging them to innovate and develop better environments to learn in. The results of Sorrell Foundation projects have not only been extremely positive, but also highly creative. 
The process is much like any professional design process used by companies all over the world. A pupil client team is formed within a school with the support of a lead teacher and the senior management. The client team then works to become familiar with design implications so that they can provide a brief for their designer. They identify areas within the school that could be improved before visiting inspirational examples of the built environment where design has been used to develop innovative spaces. The idea is to observe spaces that will provide the client with ideas and hopefully get them to question traditional design responses or, in some cases, have that "eureka" moment.

If, for example, clients wanted to transform a learning space, they could benefit from visiting well-designed public libraries or flexible and creative learning centres in cultural buildings. If they wanted to change their dining space, they could visit high street food outlets where the services is prompt, the variety of food is diverse and the environment is suited to different types of eating, whether it be on the go or sit down.

Once informed, the client is then in a position to carry out research within the school before setting a creative and visual brief for their designer or architect. This could be in all manner of forms including film, theatre, presentations and even song. Most prepare a visual brief or "pupils' brief", which outlines how the space is currently being used and suggests how it could be improved, drawing on their knowledge and examples to offer solutions.

A designer or architect then works with the client team to further their experience and deepen their research. A fruitful client/designer relationship leads to the exchange of ideas and, ultimately, evolves into a design concept that is presented back to the pupil clients. This key element of the process allows the pupil clients to be honest in their feedback of the design concept. Were it not to match the brief then the designer or architect would need to go back to the drawing board to develop the idea before final approval.

This method was proved a success in all participating schools in the United Kingdom and has developed and evolved into larger capital investment programmes. Some of the original projects received funding from their English Local Authority to implement their ideas and continue to demonstrate the value of involving the pupils as clients.

At Acland Burghley School in London, a mixed secondary school, the Sorrell Foundation's "Joinedupdesignforschools" programme matched a pupil client team with SHH Architects, experts in fast food and canteen design. The client team took $\mathrm{SHH}$ on a tour of their existing canteen which they felt was suffering from poor hygiene, cramped spaces, dilapidated furniture and little outside space to eat in. They then presented a visual "brief" to $\mathrm{SHH}$ and spelled out the problems with the existing canteen. $\mathrm{SHH}$ took the client team on a tour of a restaurant they had designed and then engaged in a conversation about how good design, driven by the pupils' ideas, could have a positive impact on the space. A design concept evolved and the school received support from the local authority to create the new canteen. Its features include outdoor spaces, eating areas for a quick lunch or a working lunch (the pupils' brief requested an Internet café) and comfortable furniture. The space transformed the pupils' experience of lunchtime at school, a fundamental part of their day.

At Westminster Academy, also in London, a new building was completed in 2007 as part of the former UK government's city academy programme. The architects, Allford Hall Monaghan Morris, worked with pupils as clients to identify key issues for the new building. One area of concern for the clients was the toilets. Often cited as a common issue for children and young people in schools, the pupils demonstrated the issues around lack of respect which then led to vandalism and poor hygiene. 


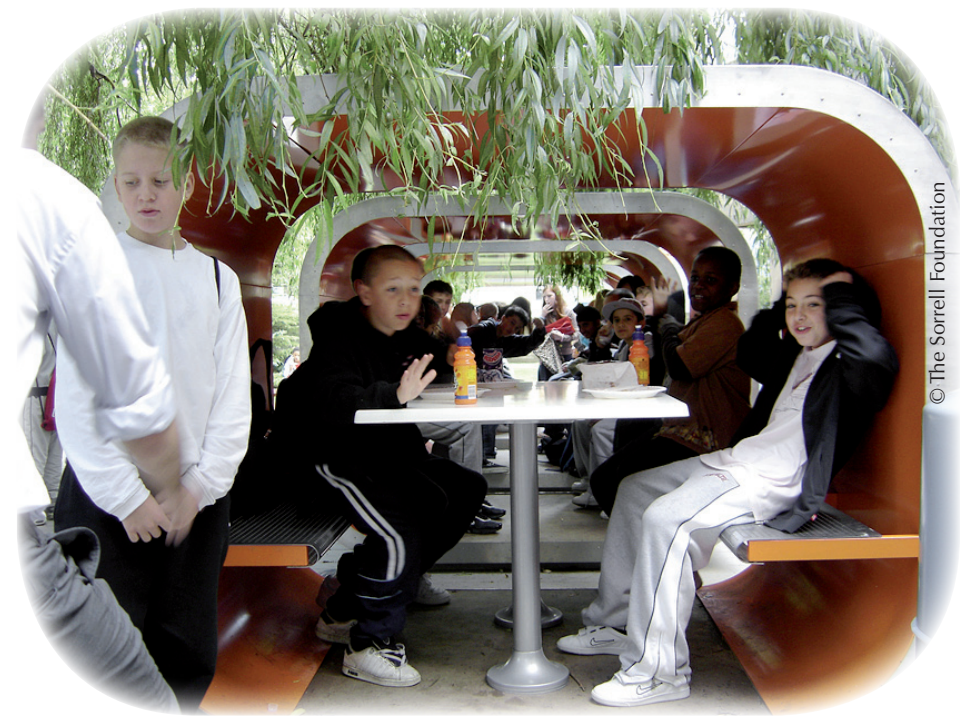

Acland Burghley

outdoor canteen pods

They also pinpointed the toilets as areas susceptible to bullying. Working with the client team, the architects developed a design concept that proposed private cubicles and wash basin facilities and an entrance and exit at both ends of the toilet, eliminating the issue around pupils being trapped at one end. The new toilets were a success and, along with a change of ethos in the school, have designed out the issue of bullying.

At the Milton Keynes Academy in Buckinghamshire, a pupil client team which took part in the Foundation's Joinedupdesignforschools programme worked with the architectural practice BDP and the programme's senior management team to develop a design for a building that felt welcoming. Key to the new school was the pupil clients' desire to have a brilliantly designed reception space that was a light and open area. Responding to the brief, the architects also demonstrated innovative learning environments by developing a variety of room sizes for one-to-one teaching, group learning and class size learning (up to 30 pupils). In the new building, the pupils are based in learning villages, moving to other parts of the building for practical subjects like Physical Education.

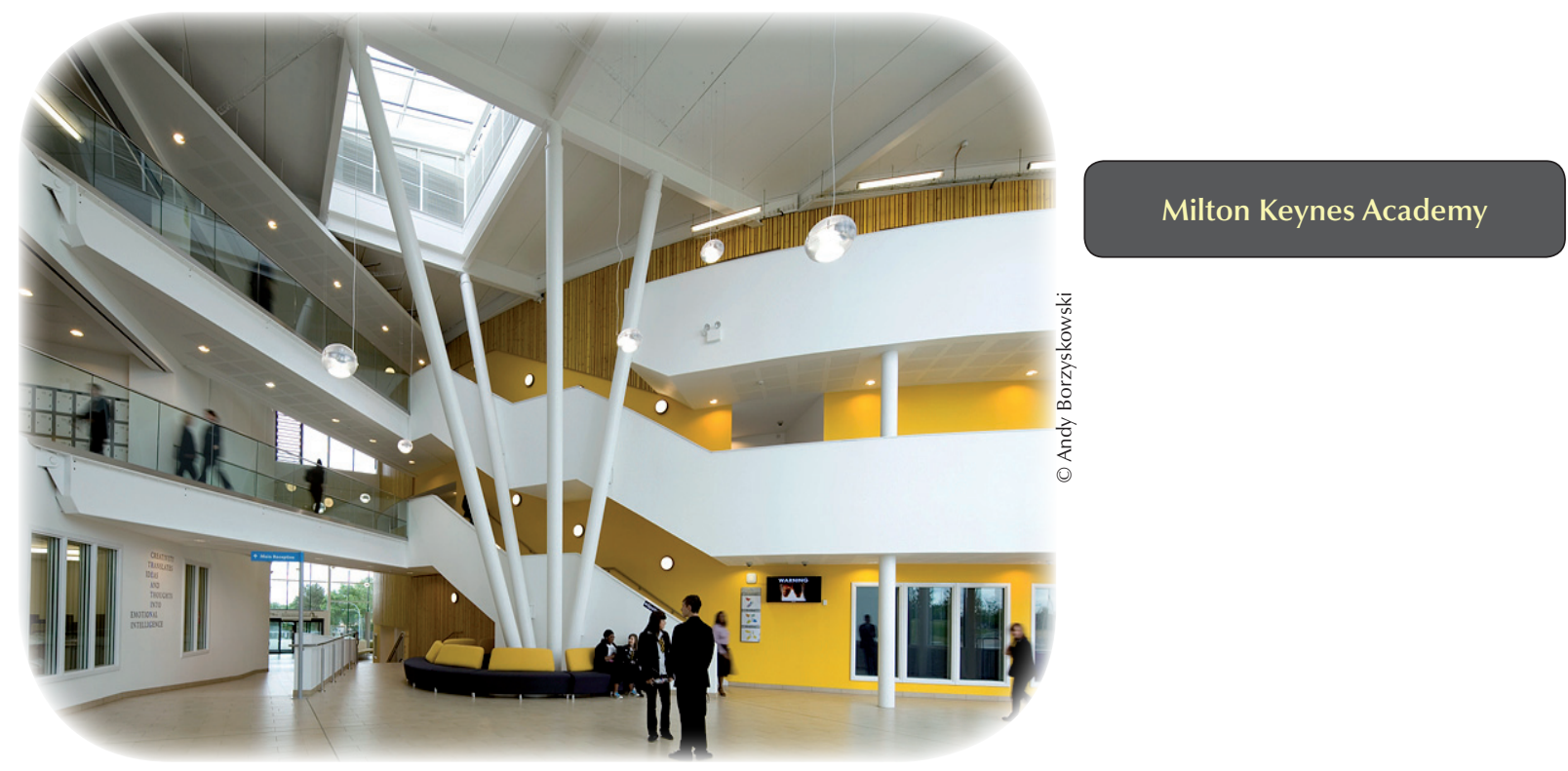


These projects have all benefited from developing a brief and design concept with their users in mind. The marriage of good design and consumer ownership leads to a better understanding by the user and ultimately a more profitable creation, whether it is for an iPhone or a new school environment. Investing in our school buildings, and involving pupils and teachers in the process, is an investment in education that has the ability to demonstrate huge social profit for societies all over the world.

For more information, contact:

Tom Doust

Special project adviser

The Sorrell Foundation

Somerset House

Strand

London WC2R 1 LA

United Kingdom

E-mail: tom@thesorrellfoundation.com

www.thesorrellfoundation.com

For more information on the activities of SHH Architects, see:

www.shh.co.uk/casestudies/bars/the_hub/the_hub.php

For more information on the activities of Allford Hall Monaghan Morris Architects, see:

www.ahmm.co.uk/projects/done/done_westminster_academy.php

For more information on the activities of BDP Architects, see: www.bdp.com 


\section{ORGANISATION FOR ECONOMIC CO-OPERATION AND DEVELOPMENT}

The OECD is a unique forum where the governments of 33 democracies work together to address the economic, social and environmental challenges of globalisation. The OECD is also at the forefront of efforts to understand and to help governments respond to new developments and concerns, such as corporate governance, the information economy and the challenges of an ageing population. The Organisation provides a setting where governments can compare policy experiences, seek answers to common problems, identify good practice and work to co-ordinate domestic and international policies.

The OECD member countries are: Australia, Austria, Belgium, Canada, Chile, the Czech Republic, Denmark, Finland, France, Germany, Greece, Hungary, Iceland, Ireland, Israel, Italy, Japan, Korea, Luxembourg, Mexico, the Netherlands, New Zealand, Norway, Poland, Portugal, the Slovak Republic, Slovenia, Spain, Sweden, Switzerland, Turkey, the United Kingdom and the United States. The Commission of the European Communities takes part in the work of the OECD.

OECD Publishing disseminates widely the results of the Organisation's statistics gathering and research on economic, social and environmental issues, as well as the conventions, guidelines and standards agreed by its members.

This work is published under the responsibility of the Secretary General of the OECD. The opinions expressed and arguments employed herein do not necessarily reflect the official views of the Organisation or of the governments of its member countries.

You can copy, download or print OECD content for your own use, and you can include excerpts from OECD publications, databases and multimedia products in your own documents, presentations, blogs, websites and teaching materials, provided that suitable acknowledgment of OECD as source and copyright owner is given. All requests for public or commercial use and translation rights should be submitted to rights@oecd.org. Requests for permission to photocopy portions of this material for public or commercial use shall be addressed directly to the Copyright Clearance Center (CCC) at info@copyright.com or the Centre français d'exploitation du droit de copie (CFC) contact@cfcopies.com. 